\title{
Decision Support System Design Structural Promotion Civil Apparatus Using AHP and TOPSIS Methods
}

\author{
Muhamad Yusuf $^{* 1}$, Kusrini ${ }^{2}$, Agung Budi Prasetio ${ }^{3}$ \\ ${ }^{1,2,3}$ Magister Teknik Informatika, Universitas AMIKOM Yogyakarta, Indonesia \\ E-mail: ${ }^{* 1}$ yusuf.1207@ students.amikom.ac.id_kusrini@amikom.ac.id, \\ 3agungbp@amikom.ac.id
}

\begin{abstract}
The quality of the performance of the State Civil Apparatus (ASN) is a very important resource to be able to determine the capacity of the Regional Apparatus Organization (OPD). One of the efforts to improve the quality of OPD performance is the promotion of positions. Promotion of an award given for work performance and dedication of a civil servant, as well as being excited to improve work performance and loyalty. Therefore, it is necessary to determine promotion. The weighting method in this study uses the Analytical Hierarchy Process. This study also compares this method with the Technique for Ordering Preference based on Similarities with Ideal Solutions. The resulting criteria are formal and informal. Consists of formal sub-criteria consisting of formal education, position experience, class rank, technical competence, managerial competence, and socio-cultural competence. Then for the informal sub-criteria consisting of discipline, innovation, creativity, ideas for institutional functions, the ability to collaborate and work in teams, loyalty, responsibility, leadership, ability to communicate well, and recommendations at the provincial and/or ministerial level. Furthermore, calculations are carried out using the AHP and TOPSIS methods for data for 2018 which means 1 position, in 2019 means 2 positions, and in 2020 means 4 positions. One position consists of 3 ASN alternatives. After comparing the accuracy level of the AHP and TOPSIS methods with experts, the results of the AHP method are better in making recommendations for structural promotion of echelon IV ASN by producing a perfect score of $100 \%$ and $a$ TOPSIS value of $71.4 \%$.
\end{abstract}

Keywords - Decision Making, Promotion, State Civil Apparatus, Analytical Hierarchy Process, Technique for Order of Preference by Similarity to Ideal Solution

\section{INTRODUCTION}

In the world of work, promotion is commonplace, including the Civil Servant profession (PNS). Unlike promotional governance in companies that meet different criteria in a promotion. Government agencies, promotion of civil servants use the same rules for all civil servants, both local government (pemda) and central government. A civil servant receives a promotion if he meets certain requirements, such as performance, education, work period, etc. With the promotion, it will automatically make civil servants have bigger salaries and benefits.

Not in line with the increase in salary and benefits, the professionalism of ASN has not been as expected. One of the main causes is the mismatch between competence and the position occupied. The mismatch of employee skills which are not yet proportional is also the cause ${ }^{[1]}$. Likewise, the distribution of employees still does not refer to the needs of the organization or is not based on the organizational performance burden. The pile of employees in one unit without a clear job and fewer employees in other units is another problem, it is the information of the problem ${ }^{[2]}$.

ASN performance quality is a very important resource and is part of the factors that can support the Regional Apparatus Organization (OPD). One of the efforts made to improve the quality of OPD performance is the promotion of positions. Promotion of reward positions that 
value ASN's professional performance and dedication and work to improve work performance and loyalty. Therefore, it is necessary to determine promotion.

The structural positions in local government consist of echelon II, echelon III, and echelon IV ${ }^{[3]}$. Tangerang Selatan City is one of the young cities in Indonesia which was formed in 2008. According to data for December 2020, there are 771 structural positions for echelon IV, which are well known in 38 OPD. The South Tangerang City Government needs to be able to increase competent officials. The city of South Tangerang has yet to have a decision support system for the promotion of structural officials that can provide information and assist the Mayor in making decisions related to the promotion of echelon IV structural positions.

The decision of the structural official is the competent authority in making decisions and policies. Like and dislike factors and political interests should not be a determining factor for promotion. Currently, the issue of promotion of structural officials is one of the issues that has received attention from several circles, given the many interests in it ${ }^{[4]}$. This is because so far the promotion process tends to use a closed system. Decision-making is the result of a problem that is firmly related ${ }^{[5]}$. A Decision Support System (DSS) is an interactive computer system, which helps decision-makers use data and models to solve structured and semistructured problems ${ }^{[6]}$. DSS does not exist to automate decision-makers but provides interactive tools for decision-makers to perform various analyzes using available models ${ }^{[7]}$.

DSS has been widely used in various fields of study to assist decision-makers. One of them is a research conducted by Barusman et al., (2020) entitled "Order of Civil Civil Structural Position (ASN)", which establishes the formal criteria for compiling the career patterns of civil servants in 2011 and informally in interviews. The criteria consist of formal education, rank/class, position training, job experience, work period, and age. Meanwhile, informal criteria are informal criteria, innovation, creativity, creativity, creativity, and teamwork, loyalty, responsibility, leadership, creativity, and political intervention ${ }^{[1]}$.

In the research of Dewi et al., (2019) using the AHP method. When each criterion (criterion) and alternative (student) will be compared with other students to produce a priority intensity value that results in an assessment of each student ${ }^{[8]}$. Furthermore, another study conducted by Rahim et al., (2018) this study uses the DSS method used is the TOPSIS method. The criteria used in selecting the best employees are job responsibilities, work discipline, work quality, and behavior. The result of the potential global employee priority scores is better used as a decision-making tool for better employee management ${ }^{[9]}$.

The AHP and TOPSIS methods are also used in the ISWARI, ARINI, and Muslim research (2019) this research has developed the DSS for selecting students with a presentation by combining the AHP and TOPSIS Methods. The results of the presentation using Hamming Distance, 93\%. Although the application of the AHP-TOPSIS combination method accepts the results of the presentation using the mismatch of the $91 \%$ Hamming Distance based on these results in this study, it can be concluded that the AHP-TOPSIS combination method is better than the TOPSIS method ${ }^{[10]}$. Then, the use of AHP and the TOPSIS method is also used by Sari et al., (2018) combining the AHP and TOPSIS methods to optimize the weight of the criteria weights that affect the results of the ranking alternatives in a more objective way. The resulting Hamming distance was $96.2 \%$ and Euclidean distance 0.8096 for 95 students ${ }^{[1]}$.

\section{RESEARCH METHOD}

This research was conducted at the Regional Apparatus of the Badan Kepegawaian, Pendidikan dan Pelatihan (BKPP) of South Tangerang City, which is located in the South Tangerang City Government office, Jl. Maruga Raya Gedung 2 1st floor, Serua, Ciputat Kota Tangerang Selatan, Banten 15414. This research has obtained permission from the Head of BKPP as the highest leader in OPD BKPP. Furthermore, the Head of BKPP disposes him to the Section Head and Head of the Agency related to the promotion. Researchers used primary data belonging to OPD BKPP, and conducted in-depth interviews, namely the process of 
obtaining information for research purposes with face-to-face questions and responses between the interviewer and the interviewee with or without using interviewer guidelines where the interviewer and informants are involved in a relatively long social life. ${ }^{[12]}$. The purpose of in-depth interviews in this study is to determine what criteria are needed in assessing ASN in a structural promotion of echelon IV. Interviews were conducted with the Head of the Appointment and Transfer Section at the South Tangerang City BKPP and the Head of the Mutation Division at the South Tangerang City BKPP to find out what criteria are needed in assessing ASN in the structural promotion. The research data used is data from 2018-2020. The total sample of data that the researchers received from the Head of the Mutation Division was 7 positions with 1 position in 2018, 2 positions in 2019, and 4 positions in 2020. One position consists of 3 alternative ASN candidates for echelon IV structural officials. The research flow can be seen in Figure 1.

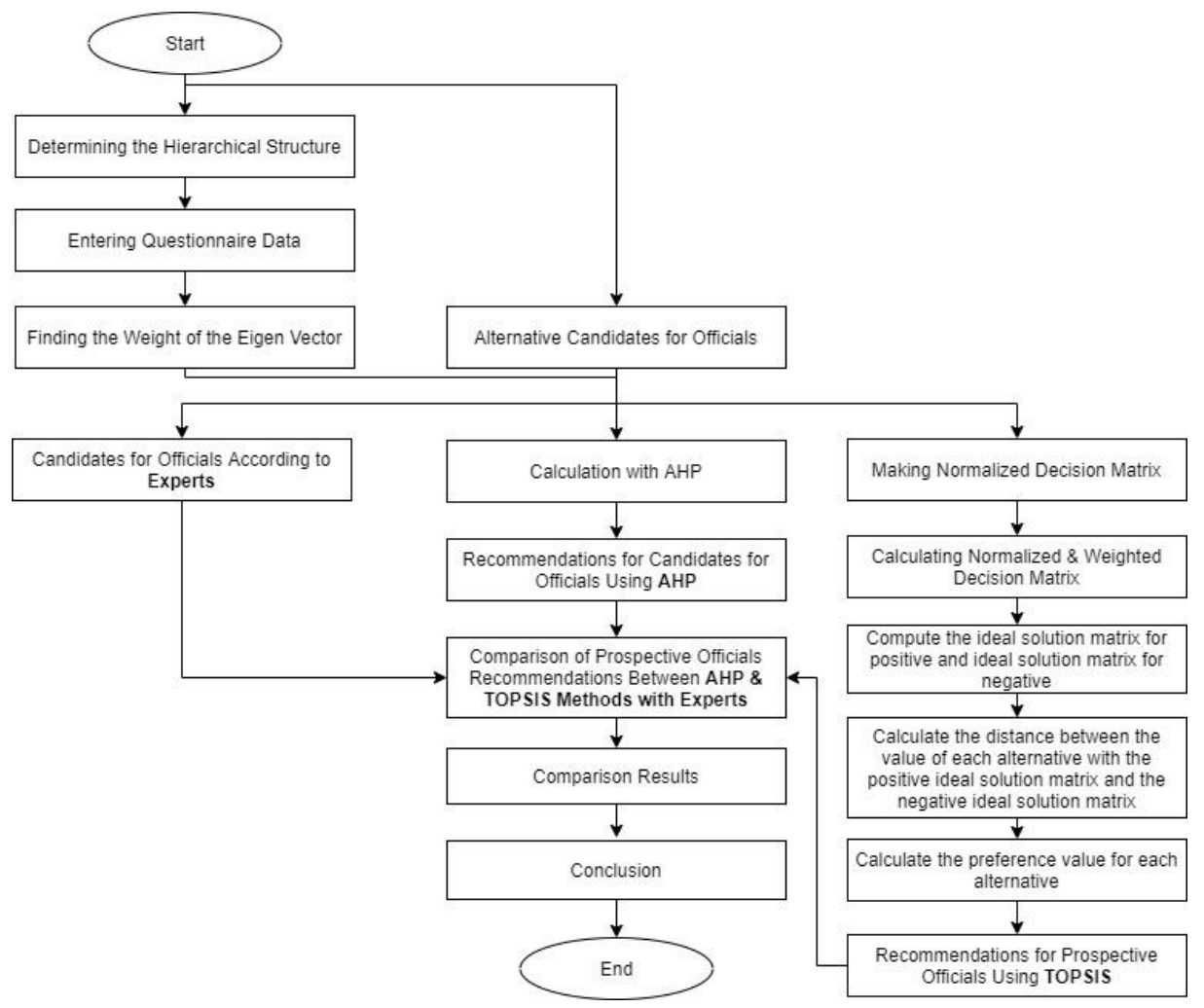

Figure 1. Research Flow

The tool used in this research is the analytic hierarchy process (AHP). AHP aims to simplify the factors obtained when conducting interviews in a hierarchy so that they appear more structured and more systematic. The interview is one of the data collection techniques for qualitative researchers. Different from other methods, the interview has unique features that make it superior ${ }^{[13]}$. A suitable method and calculation of the consistency value to determine the priority level of criteria is the AHP method ${ }^{[14]}$. AHP is often used as a problemsolving method compared to other methods for the following reasons: 1 . A structure which is a hierarchy, as a result of the criteria chosen, on the deepest sub-criteria; 2. Considering the validity of the tolerance limits of various criteria and alternatives chosen by the decisionmaker; 3. take into account the output power from the sensitivity analysis of decision making ${ }^{[15]}$. In general, the steps for using the AHP method to solve the problem are as follows. ${ }^{[10]}$ : 
1. Create a Pairwise Comparison Matrix

$$
A=\left[r_{i m}\right]=\left[\begin{array}{cccc}
1 & r_{12} & \cdots & r_{n 2} \\
\frac{1}{r_{12}} & 1 & \cdots & r_{2 n} \\
\cdots & \cdots & \cdots & \cdots \\
\frac{1}{r_{1 n}} & \frac{1}{r_{2 n}} & \cdots & 1
\end{array}\right]
$$

2. Normalize the Decision Matrix

Description:

$$
\bar{x}_{i}=r_{1 i}+r_{2 i}+\cdots+r_{n i}
$$

$\bar{x}_{i}=$ Number of matrix columns

$i=$ Column variable $\mathrm{i}$

$n=$ Variable line $\mathrm{n}$

$r=$ Pairwise Comparison Matrix Index

3. Determining the Weight of the Criteria

Description:

$$
\bar{x}_{j}=r_{1 i}{ }^{\prime}+r_{2 i}{ }^{\prime}+\cdots+r_{n i}{ }^{\prime}
$$

$\bar{x}_{j}=$ Number of matrix columns

$i=$ Column variable $\mathrm{i}$

$j=$ Variable line $j$

$n=$ Variable line $n$

$r^{\prime}=$ Decision Matrix Normalization

4. Then Calculate the Criteria Weight

Description:

$$
w_{i}=\frac{\bar{x}_{j}}{n}
$$

$$
\begin{aligned}
w_{i} & =\text { Number of matrix columns } \\
i & =\text { Column variable } \mathrm{i} \\
j & =\text { Variable line } j \\
n & =\text { Variable line } n \\
w^{n} & =\text { Criteria weights }
\end{aligned}
$$

This study also used the TOPSIS method to choose existing alternatives. TOPSIS is one of the multicultural decision-making methods first introduced by Yoon and Hwang in 1981. TOPSIS uses the principle that the chosen alternative must have the closest distance to the ideal positive solution and the longest distance (farthest) from the negative ideal (farthest). The solution from a geometric point of view with a geometric point of view uses the Euclidean distance (two points) to determine the relative proximity of an alternative ${ }^{[16]}$.

In general, the TOPSIS method procedure follows these steps ${ }^{[17]}$ :

1. Determine the normalized decision matrix.

$$
\begin{gathered}
r_{i j}=\frac{x_{i j}}{\sqrt{\sum_{i=1}^{m} x_{i j}^{2}}} \\
\text { with } \quad{ }_{i}=1,2, \ldots, \mathrm{m} \quad{ }_{j}=1,2, \ldots, \mathrm{n}
\end{gathered}
$$

2. Calculates a weighted normalized decision matrix.

$$
y_{i j}=w_{i} r_{i j}
$$


3. Calculates the positive ideal solution matrix and the negative ideal solution matrix.

$$
\begin{aligned}
& A^{+}=y_{1}{ }^{+}, y_{1}{ }^{+}, \ldots, y_{n}{ }^{+} \\
& A^{-}=y_{1}{ }^{-}, y_{1}{ }^{-}, \ldots, y_{n}{ }^{-}
\end{aligned}
$$

4. Calculating the distance between the value of each alternative with the positive ideal solution matrix and the negative ideal solution matrix.

$$
\begin{gathered}
D_{i}^{+}=\sqrt{\sum_{j=1}^{n}\left(y_{i}^{+}-y_{i j}\right)^{2}} \\
D_{i}^{-}=\sqrt{\sum_{j=1}^{n}\left(y_{i j}-y_{i}\right)^{2}} \\
j=1,2, \ldots, \mathrm{n}
\end{gathered}
$$

5. Calculate the preference value for each alternative

$$
V_{i}=\frac{D_{i}^{-}}{D_{i}^{-}+D_{i}^{+}}
$$

To evaluate the results of the DSS recommendations and to avoid the like and dislike factors as well as political interests, this study uses experts to make promotion decisions for echelon IV structural officials. The expert selected in the ASN structural position promotion is the Head of the South Tangerang City BKPP Transfer Division. The reason for choosing the expert was due to (1) experience in providing joint Badan Pertimbangan Jabatan dan Kepangkatan (BAPERJAKAT), (2) knowledge of the rules for promotion of echelon IV structural positions, (3) as well as their main duties and functions. The main duties and functions of the Head of the South Tangerang City BKPP Transfer Division are to provide administrative services for appointments, transfers, ranks, dismissals, presentation of personnel data and information. So that to calculate the accurate value of the DSS using Equation 10.

$$
\text { Accuracy }=\frac{\text { Amount of data is appropriate }}{\text { Number of samples }} \times 100 \%
$$

\section{RESULTS AND DISCUSSION}

In designing a system based on the AHP method for decision making, the first step that must be taken is to define the problem and determine the goal by arranging it into a hierarchy ${ }^{[18]}$. Then, it determines the criteria to be assigned weights ${ }^{[18]}$. Based on the criteria researched by Barusman et al., (2020), the ASN promotion criteria consist of formal and informal. In this study, after the researcher conducted in-depth interviews with sources, there was a use of different rules, which led to differences in the sub-criteria used. In the research conducted by Suhun and Dwiyanto (2020) at Disbunnak, Lampung Province, it was determined that the formal sub-criteria were based on the guidelines for the preparation of the Career Patterns for Civil Servants in 2011, while at BKPP South Tangerang City used criteria based on Government Regulation No. Then differences are also found in the informal sub-criteria, this occurs because of differences in views and experiences of interviewees and does not rule out changes in the criteria and sub-criteria policies in the future. Furthermore, the formal criteria consist of formal education, job experience, class rank, technical competence, managerial competence, and socio-cultural competence. Then for the informal sub-criteria consisting of discipline, innovation, creativity, ideas for developing institutional functions, the 
ability to collaborate and work in teams, loyalty, responsibility, leadership, ability to communicate well, and recommendations at the provincial and/or ministerial level. The AHP hierarchy can be seen in Figure 2.

Objective

Criteria

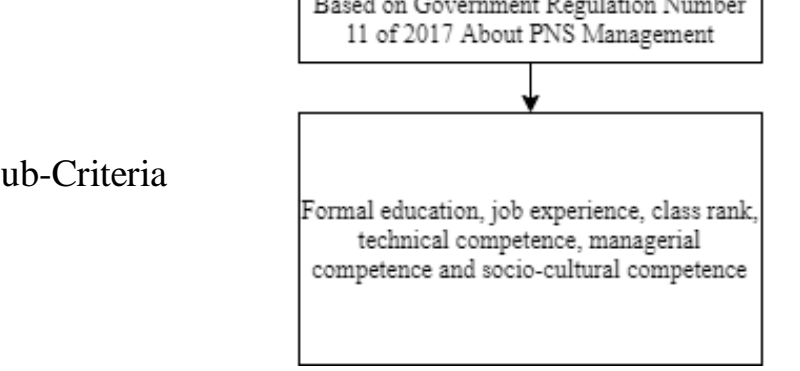
Building DSS Promotion for Structural Position IV ASN in South Tangerang City

Fugure 2. AHP hierarchy

In measuring the level of importance between sub-criteria, the weighting of the intensity of importance is carried out by comparing the level of importance between the sub-criteria. The weighting is by the AHP theory which can be seen in Table 1 .

Tabel 1. Intensity of interest

\begin{tabular}{cl}
\hline Intensity of Importance & \multicolumn{1}{c}{ Definition } \\
\hline $\mathbf{1}$ & These two elements are also important \\
\hline $\mathbf{3}$ & Elements are a little more important than others \\
\hline $\mathbf{5}$ & Element is more important than others \\
\hline $\mathbf{7}$ & Element is very important that other elements \\
\hline $\mathbf{9}$ & The absolute element is more important than the other elements \\
\hline $\mathbf{2 , 4 , 6 , 8}$ & The mean in two adjacent comparisons \\
\hline
\end{tabular}

The level of importance is filled in by the Head of the BKPP Mutation Division, who according to the regulations has the main task and function of providing administrative services for appointing officials. The results of the pairwise comparison matrix are obtained as in Table 2. Furthermore, the calculation of the level of importance is carried out to determine the priority value of each criterion using formulas 2,3 , and 4 . The results of the weights are obtained and the calculation is carried out on the sample data such as in Table 3 and Table 4. All criteria in determining the structural promotion of echelon IV, this has the nature of advantages.

Table 2. Pairwise comparison matrix

\begin{tabular}{|c|c|c|c|c|c|c|c|c|c|c|c|}
\hline F. & FORMAL CRITERIA & F.1. & F.2. & F.3. & F.4. & F.5. & F.6. & & & & \\
\hline F.1. & Formal education & 1,000 & 9,000 & 9,000 & 9,000 & 9,000 & 9,000 & & & & \\
\hline F.2. & Job Experience & 0,111 & 1,000 & 7,000 & 7,000 & 7,000 & 7,000 & & & & \\
\hline F.3. & Group Rank & 0,111 & 0,143 & 1,000 & 1,000 & 1,000 & 1,000 & & & & \\
\hline F.4. & Technical Competence & 0,111 & 0,143 & 1,000 & 1,000 & 5,000 & 5,000 & & & & \\
\hline F.5. & Managerial Competence & 0,111 & 0,143 & 1,000 & 0,200 & 1,000 & 1,000 & & & & \\
\hline F.6. & Socio-Cultural Competence & 0,111 & 0,143 & 1,000 & 0,200 & 1,000 & 1,000 & & & & \\
\hline I. & INFORMAL CRITERIA & I.1. & I.2. & I.3. & I.4. & I.5. & I.6. & I.7. & I.8. & I.9. & I.10 \\
\hline I.1. & Discipline & 1,000 & 7,000 & 7,000 & 7,000 & 7,000 & 5,000 & 5,000 & 5,000 & 3,000 & 3,000 \\
\hline
\end{tabular}


ISSN : 1978-8282, Online ISSN: 2655-4275

\begin{tabular}{|c|c|c|c|c|c|c|c|c|c|c|c|}
\hline I.2. & Innovation & 0,143 & 1,000 & 3,000 & 3,000 & 0,200 & 0,143 & 0,143 & 0,143 & 0,111 & 0,111 \\
\hline I.3. & Creativity & 0,143 & 0,333 & 1,000 & 1,000 & 0,200 & 0,200 & 0,200 & 0,143 & 0,143 & 0,111 \\
\hline I.4. & $\begin{array}{l}\text { Institutional Function } \\
\text { Development Ideas }\end{array}$ & 0,143 & 0,333 & 1,000 & 1,000 & 3,000 & 0,200 & 1,000 & 3,000 & 1,000 & 0,111 \\
\hline I.5. & $\begin{array}{l}\text { Ability To Collaborate And } \\
\text { Work Together In Teams }\end{array}$ & 0,143 & 5,000 & 5,000 & 0,333 & 1,000 & 0,143 & 1,000 & 0,333 & 1,000 & 0,143 \\
\hline I.6. & Loyalty & 0,200 & 7,000 & 5,000 & 5,000 & 7,000 & 1,000 & 0,143 & 0,143 & 0,200 & 0,200 \\
\hline I.7. & Responsible & 0,200 & 7,000 & 5,000 & 1,000 & 1,000 & 7,000 & 1,000 & 4,000 & 4,000 & 1,000 \\
\hline I.8. & Leadership & 0,200 & 7,000 & 7,000 & 0,333 & 3,000 & 7,000 & 0,250 & 1,000 & 1,000 & 0,200 \\
\hline I.9. & Ability To Communicate Well & 0,333 & 9,000 & 7,000 & 1,000 & 1,000 & 5,000 & 0,250 & 1,000 & 1,000 & 0,200 \\
\hline \multirow[t]{2}{*}{ I.10. } & $\begin{array}{l}\text { Provincial and / or Central } \\
\text { Level Recommendations }\end{array}$ & 0,333 & 9,000 & 9,000 & 9,000 & 7,000 & 5,000 & 1,000 & 5,000 & 5,000 & 1,000 \\
\hline & Formal Informal & & & & & & & & & & \\
\hline Formal & 9,000 & & & & & & & & & & \\
\hline \multirow[t]{2}{*}{ Informal } & 0,111 & & & & & & & & & & \\
\hline & Criteria Formal Education & F.1.1. & F.1.2. & F.1.3. & F.1.4. & & & & & & \\
\hline F.1.1. & D3 & 1,000 & 0,500 & 0,333 & 0,250 & & & & & & \\
\hline F.1.2. & S1 & 2,000 & 1,000 & 0,500 & 0,333 & & & & & & \\
\hline F.1.3. & S2 & 3,000 & 2,000 & 1,000 & 0,500 & & & & & & \\
\hline \multirow[t]{2}{*}{ F.1.4. } & S3 & 4,000 & 3,000 & 2,000 & 1,000 & & & & & & \\
\hline & Criteria Group Rank & F.3.1. & F.3.2. & F.3.3. & F.3.4. & F.3.5. & & & & & \\
\hline F.3.1. & IIIb & 1,000 & 0,500 & 0,333 & 0,250 & 0,200 & & & & & \\
\hline F.3.2. & IIIc & 2,000 & 1,000 & 0,500 & 0,333 & 0,250 & & & & & \\
\hline F.3.3. & IIId & 3,000 & 2,000 & 1,000 & 0,500 & 0,333 & & & & & \\
\hline F.3.4. & IVa & 4,000 & 3,000 & 2,000 & 1,000 & 0,500 & & & & & \\
\hline F.3.5. & $\mathrm{IVb}$ & 5,000 & 4,000 & 3,000 & 2,000 & 1,000 & & & & & \\
\hline
\end{tabular}

Description:

$\mathbf{F}=$ Criteria Formal

$\mathbf{I}=$ Criteria Informal

Table 3. Weights for Sub Criteria F.1. Formal Education and Weight for Sub-Criteria F.3

\section{WEIGHT}

\begin{tabular}{cc}
\hline F.1.1. & 0,096 \\
\hline F.1.2. & 0,161 \\
\hline F.1.3. & 0,277 \\
\hline F.1.4. & 0,466 \\
\hline F.3.1. & 0,062 \\
\hline F.3.2. & 0,099 \\
\hline F.3.3. & 0,161 \\
\hline F.3.4. & 0,262 \\
\hline F.3.5. & 0,416 \\
\hline
\end{tabular}


Table 4. Alternatives to filling X1 positions in 2018

\begin{tabular}{lcccc}
\hline & Weight & Alternative A & Alternative B & Alternative C \\
\hline F.1. & 0,478 & 0,644 & 0,644 & 0,644 \\
\hline F.2. & 0,222 & 2 & 4 & 4 \\
\hline F.3. & 0,041 & 0,262 & 0,161 & 0,099 \\
\hline F.4. & 0,091 & 85 & 80 & 80 \\
\hline F.5. & 0,034 & 90 & 80 & 75 \\
\hline F.6. & 0,034 & 90 & 85 & 80 \\
\hline I.1. & 0,027 & 90 & 85 & 80 \\
\hline I.2. & 0,003 & 85 & 80 & 75 \\
\hline I.3. & 0,002 & 85 & 80 & 75 \\
\hline I.4. & 0,005 & 85 & 80 & 80 \\
\hline I.5. & 0,005 & 85 & 80 & 80 \\
\hline I.6. & 0,008 & 90 & 80 & 75 \\
\hline I.7. & 0,013 & 90 & 85 & 80 \\
\hline I.8. & 0,009 & 90 & 80 & 70 \\
\hline I.9. & 0,008 & 90 & 80 & 80 \\
\hline I.10. & 0,020 & 90 & 80 & 80 \\
\hline & & & &
\end{tabular}

Furthermore, calculations are carried out using the AHP method on the data in Table 4. The results were:

Alternative 1 - A $(0,644 * 0,478)+(2 * 0,222)+(0,262 * 0,041)+(85 * 0,091)+(90$ $* 0,034)+(90 * 0,034)+(90 * 0,027)+(85 * 0,003)+(85 * 0,002)+(85 * 0,005)+(85 * 0,005)+(90 * 0,008)$ $+(90 * 0,013)+(90 * 0,009)+(90 * 0,008)+(90 * 0,020)=23,543$

Alternative 2 - B $(0,644 * 0,478)+(4 * 0,222)+(0,161 * 0,041)+(80 * 0,091)+(85$ $* 0,034)+(85 * 0,034)+(85 * 0,027)+(80 * 0,003)+(80 * 0,002)+(80 * 0,005)+(80 * 0,005)+(80 * 0,008)$ $+(85 * 0,013)+(80 * 0,009)+(80 * 0,008)+(80 * 0,020)=22,462$

Alternative 3 - C $(0,644 * 0,478)+(4 * 0,222)+(0,099 * 0,041)+(80 * 0,091)+(75$ $* 0,034)+(80 * 0,034)+(80 * 0,027)+(75 * 0,003)+(75 * 0,002)+(80 * 0,005)+(80 * 0,005)+(75 * 0,008)$ $+(80 * 0,013)+(80 * 0,009)+(80 * 0,008)+(80 * 0,020)=21,685$

Then perform calculations using the TOPSIS method with the weight values that have been generated in the AHP calculation, here are the steps:

1. Determine the normalized decision matrix, using the formula 6 . The results obtained are as in Table 5 .

Table 5. Normalized decision matrix to fill the position of X1 in 2018

\begin{tabular}{clllllllllll}
\hline ALTERNATIVE & F.1. & F.2. & F.3. & F.4. & F.5. & F.6. & & & & \\
\hline A & 0,577 & 0,333 & 0,811 & 0,601 & 0,634 & 0,611 & & & & \\
\hline B & 0,577 & 0,667 & 0,499 & 0,565 & 0,564 & 0,577 & & & & \\
C & 0,577 & 0,667 & 0,305 & 0,565 & 0,529 & 0,543 & & & & \\
\hline ALTERNATIVE & I.1. & I.2. & I.3. & I.4. & I.5. & I.6. & I.7. & I.8. & I.9. & I.10 \\
\hline A & 0,611 & 0,613 & 0,613 & 0,601 & 0,601 & 0,634 & 0,611 & 0,623 & 0,623 & 0,623 \\
\hline B & 0,577 & 0,577 & 0,577 & 0,565 & 0,565 & 0,564 & 0,577 & 0,553 & 0,553 & 0,553 \\
\hline C & 0,543 & 0,541 & 0,541 & 0,565 & 0,565 & 0,529 & 0,543 & 0,553 & 0,553 & 0,553 \\
\hline
\end{tabular}

2. Calculating the weighted normalized decision matrix, using the formula 7 . The results are shown in Table 6 . 
Table 6. Weighted normalized decision matrix to fill the position of X1 in 2018

\begin{tabular}{cllllllllll}
\hline ALTERNATIVE & F.1. & F.2. & F.3. & F.4. & F.5. & F.6. & & & & \\
\hline A & 0,276 & 0,074 & 0,033 & 0,055 & 0,022 & 0,021 & & & & \\
B & 0,276 & 0,148 & 0,020 & 0,051 & 0,019 & 0,020 & & & & \\
\hline C & 0,276 & 0,148 & 0,012 & 0,051 & 0,018 & 0,019 & & & & \\
\hline ALTERNATIVE & I.1. & I.2. & I.3. & I.4. & I.5. & I.6. & I.7. & I.8. & I.9. & I.10 \\
\hline A & 0,016 & 0,002 & 0,001 & 0,003 & 0,003 & 0,005 & 0,008 & 0,005 & 0,005 & 0,012 \\
\hline B & 0,016 & 0,002 & 0,001 & 0,003 & 0,003 & 0,005 & 0,008 & 0,005 & 0,005 & 0,011 \\
\hline C & 0,015 & 0,002 & 0,001 & 0,003 & 0,003 & 0,004 & 0,007 & 0,005 & 0,005 & 0,011 \\
\hline
\end{tabular}

3. Furthermore, using the formula 8 , to calculate the ideal solution matrix positive and ideal solution negative matrix. The results were shown in Table 7.

Table 7. Matrix of positive ideal solution and negative ideal solution matrix to fill the position of X1

\begin{tabular}{clllllllllll} 
& \multicolumn{10}{c}{ in 2018} \\
\hline ALTERNATIVE & F.1. & F.2. & F.3. & F.4. & F.5. & F.6. & & & & \\
\hline Max & 0,276 & 0,148 & 0,033 & 0,055 & 0,022 & 0,021 & & & & \\
\hline Min & 0,276 & 0,074 & 0,012 & 0,051 & 0,018 & 0,019 & & & & \\
\hline ALTERNATIVE & I.1. & I.2. & I.3. & I.4. & I.5. & I.6. & I.7. & I.8. & I.9. & I.10 \\
\hline Max & 0,016 & 0,002 & 0,001 & 0,003 & 0,003 & 0,005 & 0,008 & 0,005 & 0,005 & 0,012 \\
\hline Min & 0,015 & 0,002 & 0,001 & 0,003 & 0,003 & 0,004 & 0,007 & 0,005 & 0,005 & 0,011 \\
\hline
\end{tabular}

4. Then the next step is to calculate the distance between the value of each alternative with the positive $(\mathrm{D}+)$ \& negative (D-) ideal solution matrix, using the formula 9 . The results are as shown in Table 8.

Table 8. Positive (D +) \& negative (D-) ideal solution for filling X1 positions in 2018

\begin{tabular}{cccc}
\hline ALTERNATIVE & \multicolumn{3}{c}{ SOLUSI IDEAL } \\
\cline { 2 - 4 } & D+ & \multicolumn{2}{c}{ D- } \\
\hline A & 0,074 & 0,022 \\
\hline B & 0,014 & 0,074 \\
\hline C & & 0,022 & 0,074 \\
\hline
\end{tabular}

5. The final stage in TOPSIS is to calculate the preference value for each alternative to produce a ranking for each alternative, using formula 9. The results are obtained as Table 9.

Table 9. Preference and ranking values for filling X1 positions in 2018

\begin{tabular}{crc}
\hline ALTERNATIVE & PREFERENSI & RANKING \\
\hline A & 0,226 & 3 \\
\hline B & 0,846 & 1 \\
\hline C & 0,774 & 2 \\
\hline
\end{tabular}

From the calculation of AHP with TOPSIS, there are differences in the order of recommendations, the difference is that in the AHP method Alternative A comes first, while in the TOPSIS method Alternative A comes third. Furthermore, calculations using AHP and TOPSIS were carried out in stages 7 times, consisting of 1 position (X1) for 2018, 2 positions for 2019 (X2 and X3), and 4 positions for 2020 (X4, X5, X6, and X7). There are differences in the appointment of officials between the opinion of the expert and those who have been appointed as officials, the data is in Position X6 in 2020 and Position X7 in 2020. In X6 and 
X7 according to the expert, Alternative B should occupy that position but alternative A. avoiding like and dislike factors as well as political interests as well as criteria outside the categories and sub-criteria that have been studied, the researchers use the views of experts. So that the results of the comparison of the recommendations of the DSS for structural official candidates are obtained as in Table 10.

Table 10. Comparison of the results of promotion recommendations

\begin{tabular}{lllll}
\hline No & Name of Position & Expert & AHP & TOPSIS \\
\hline $\mathbf{1}$ & Position X1 in 2018 & Alternative A & Alternative A & Alternative B \\
\hline $\mathbf{2}$ & Position X2 in 2019 & Alternaitf A & Alternative A & Alternative A \\
\hline $\mathbf{3}$ & Position X3 in 2019 & Alternative A & Alternative A & Alternative A \\
\hline $\mathbf{4}$ & Position X4 in 2020 & Alternative A & Alternative A & Alternative A \\
\hline $\mathbf{5}$ & Position X5 in 2020 & Alternative A & Alternative A & Alternative C \\
\hline $\mathbf{6}$ & Position X6 in 2020 & Alternative B & Alternative B & Alternative B \\
\hline $\mathbf{7}$ & Position X7 in 2020 & Alternative B & Alternative B & Alternative B \\
\hline
\end{tabular}

The difference in DSS recommendations is in the position data X1 in 2018 where AHP recommends Alternative A and TOPSIS recommends Alternative B. Furthermore, the latest difference is in Position X5 in 2020, the AHP method recommends Alternative A and TOPSIS recommends Alternative B. AHP and TOPSIS methods recommend the same alternative. Based on these comparisons, the accuracy of AHP and TOPSIS is compared with experts using formula 10, the results are 100\% AHP accuracy, and 71.4\% TOPSIS accuracy.

\section{CONCLUSION}

Based on the research, analysis, and discussion that has been carried out, it can be concluded that after conducting interviews with the speakers, the assessment criteria for ASN promotion are categorized into 2 criteria, namely formal and informal. The formal sub-criteria are based on Government Regulation Number 11 of 2017 concerning Civil Servant Management, consisting of formal education, job experience, rank, technical competence, managerial competence, and socio-cultural competence. Then for the informal sub-criteria consisting of discipline, innovation, creativity, ideas for developing institutional functions, the ability to collaborate and work in teams, loyalty, responsibility, leadership, ability to communicate well, and recommendations at the provincial and/or ministerial level. Then the weighting method used to obtain a decision-making model for the promotion of structural positions Echelon IV ASN at BKPP South Tangerang City is AHP. Furthermore, the calculation is carried out using the AHP and TOPSIS methods for 2018 data of 1 position, in 2019 there are 2 positions, and in 2020 there are 4 positions. One position consists of 3 ASN alternatives. After comparing the accuracy level of the AHP and TOPSIS methods with experts, the results of differences in DSS recommendations are in the X1 position data in 2018 and X5 position data in 2020, so that the results of the AHP method are better in making recommendations for structural promotion of echelon IV ASN positions with produces a perfect score that is $100 \%$ and the TOPSIS accuracy value is $71.4 \%$.

\section{SUGGESTED}

Based on the conclusions obtained, it is advisable to use the criteria and sub-criteria that have been researched as a reference, input, or consideration of Badan Pertimbangan Jabatan dan Kepangkatan (BAPERJAKAT) in making recommendations to support the promotion of echelon IV ASN positions. To make it easier for decision-makers for promotion of positions, it 
is better if WEB, Mobile, or Desktop based applications are made whose criteria and subcriteria are dynamic or can be changed according to the decision makers' needs, and apply the AHP method, which according to the level of accuracy compared to TOPSIS is better. So that the assessment of the results is more objective.

\section{REFERENCES}

[1.] M. Y. Barusman, A. Citra, M. Oktavianur, dan A. Redaputri, "Pengambilan Keputusan Penempatan Jabatan Struktural Aparatur Sipil Negara (ASN)," J. Apl. Bisnis dan Manaj., vol. 6, no. 3, hal. 459-467, 2020.

[2.] A. G. E. Tuwonaung, M. Mantiri, dan A. Kimbal, "KEBUTUHAN DAN DISTRIBUSI APARATUR SIPIL NEGARA PRESPEKTIF PELAYANAN PUBLIK DI KELURAHAN MOTTO KECAMATAN LEMBEH UTARA KOTA BITUNG,” J. Jur. Ilmu Pemerintah., vol. 3, no. 3, hal. 1-10, 2019.

[3.] R. Gosal dan F. Singkoh, "Rekrutmen Pejabat Eselon Iii Dan Iv Kabupaten Kepulauan Sangihe," J. Eksek., vol. 1, no. 1, hal. 1-12, 2018.

[4.] M. E. Atmojo, "Faktor-Faktor Yang Mempengaruhi Penentuan Pejabat Struktural Eselon Ii Di Pemerintah Daerah Daerah Istimewa Yogyakarta," Kebijak. J. Ilmu Adm., vol. 10, no. 1, hal. 10, 2019.

[5.] S. C. (Universitas N. P. Winda, "Strategi terhadap Pengambilan Keputusan," hal. 1, 2019.

[6.] E. Turban, J. E. Aronson, dan T. P. Liang, Decision Suport System and intelligent system. New Jersey: Prentice Hall, 2005.

[7.] S. H. Saragih, "Penerapan Metode Analitycal Hierarchy process Pada Sistem Pendukung Keputusan pemilihan laptop," Teknik Informatika STMIK budi Darma, Medan, 2013.

[8.] R. Dewi, W. Verina, D. H. Tanjung, dan S. L. Rahayu, "Application of AHP Method Based on Competence for Determining the Best Graduate Students," 2018 6th Int. Conf. Cyber IT Serv. Manag. CITSM 2018, no. Citsm, hal. 1-5, 2019.

[9.] R. Rahim et al., "TOPSIS Method Application for Decision Support System in Internal Control for Selecting Best Employees," J. Phys. Conf. Ser., vol. 1028, no. 1, 2018.

[10.] V. D. Iswari, F. Y. Arini, dan M. A. Muslim, "Decision Support System for the Selection of Outstanding Students Using the AHP-TOPSIS Combination Method," Lontar Komput. J. Ilm. Teknol. Inf., vol. 10, no. 1, hal. 40, 2019.

[11.] D. R. Sari, A. P. Windarto, D. Hartama, dan S. Solikhun, "Decision Support System for Thesis Graduation Recommendation Using AHP-TOPSIS Method," J. Teknol. dan Sist. Komput., vol. 6, no. 1, hal. 1-6, 2018.

[12.] Sutopo, Metodologi Penelitian Kualitatif. Surakarta: UNS, 2006.

[13.] A. E dan A. C, "Literature Review for the Type of Interview in Qualitative Research," Int. J. Educ., vol. 9, no. 3, hal. 87-92, 2017.

[14.] M. AE dan M. H, "Penerapan metode analytical hierarchy process dalam sistem pendukung keputusan penentuan mahasiswa berprestasi," J. Siliwangi Seri Sains dan Teknol., vol. 3, no. 2, hal. 192-201, 2017.

[15.] P. SI, S. A, dan N. JS, "Penerapan Metode AHP (Analytical Hierarchy Process) untuk Pemilihan Supplier Suku Cadang di PLTD Bitung," J. ONLINE POROS Tek. MESIN UNSRAT, vol. 6, no. 1, hal. 32-44, 2017.

[16.] D. Nofriansyah, No Title, Ed.1, Cet. Yogyakarta: CV BUDI UTAMA, 2014.

[17.] F. F dan S. R, "Penerapan Metoda TOPSIS pada Analisis Penentuan Posisi Ideal Pemain Sepak Bola," Semin. Nas. Apl. Teknol. Inf., vol. August, 2016.

[18.] Mahmudah, B. LM, dan A. S, "Strategi kebijakan peningkatan jumlah mahasiswa dalam memutuskan memilih program pascasarjana di departemen ESL FEM IPB," J. Apl. Bisnis Dan Manaj., vol. 6, no. 1, hal. 154-167, 2020. 